\title{
DEATH IN THE UNDERSTANDING OF THE CONTEMPORARY WORLD
}

\author{
Fr. Prof. Ph.D. Leontin POPESCU, \\ Faculty of History Philosophy and Theology "Dunărea de Jos" University of Galați, \\ ROMANIA, \\ E-mail: prleonpopescu@yahoo.it
}

\begin{abstract}
Nowadays, death, illness, and suffering are experienced as danger: a threat to one's own physical, psychological and social identity. And what accompanies all these, particularly paralizing from a spiritual perspective, is fear; the dread that all is lost, that things cannot be controlled by means of medicine, only to reach the greatest angst: the fear of death. And, in this respect, we can say that pain, suffering and the fear of death make up the anthropological foundation of the most profound religious concept of life, in the sense that these realities show man his limitations, his finite build, that of a creature, and, consequently, determine him look beyond his limitations. The fear of death brought about angst, anxiety, passion, hatred, and despair in man's life. His need to escape death made him look for even more material elements to render him oblivious to it. The solution against despair is God: faith vanquishes despair because, by faith, man acknowledges his dependence on God, but turning within himself, at the same time.
\end{abstract}

Keywords: death; medicine; man; fear; life;

\section{INTRODUCTION}

From the beginning of time, every individual, both religious, and less spiritual, who instinctively felt the inevitable approach of death, meditated on it. All, to a smaller or a greater extent, question the sacrament of death and wonder what lies beyond it.

What is death? What happens when you die? What lies beyond death? Is there an afterlife, once you've crossed the threshold of death? What evidence do we have in this respect? How is this afterlife? What can we find out about the departed? Who is wrong: those who believe or those who do not?

What is certain is that death is inevitable for man. By definition, man is mortal, and, from this point of view, he resembles any creature on Earth. Nevertheless, man is still human even when facing death, as he is aware, and therefore experiences this perspective ${ }^{1}$. Man does not die as an animal, but tends to place this event in a universe coordinated by values and norms, where the very experience of death as humanity's most dreaded problem can find its meaning. Death presented as an inexorable ending makes man ask himself questions about his own existence. The objective answer that he can provide himself with, when facing this reality which haunts him since birth, must be sought for in a set of various thinking patterns: philosophical, psychological, theological, historical, etc., but also in the concrete bahavioural pattern.

\footnotetext{
${ }^{1}$ Dionigi TetTAmanzzI, Dizionario di Bioetica [Dictionary of Bioethics], Casale Montferrato, PIEMME, 2002 , p. 292.
} 
Man's attitude towards death expresses one of those ancestral feelings that leave a profound mark on a civilization. The history of religions testifies, during each epoch, to man's concern and worry when facing death. Only from this perspective of the religious experience can we talk about an answer to this great and frightful sacrament ${ }^{2}$ : death. Particularly if we tackle Christianity, where this experience has a profound nature of getting ready not for the physical disappearance, but for the state of bliss or torment in the eternal life. According to the worship of Christian martyrs, the dead will enter the cities and villages that had cast them out for centuries. Initially, martyrs were buried in outskirts necropoleis, that Christians and pagans shared. Yet, worshipping martyrs' burial places entailed, in their turn, funerals. Such places witnessed churches and cathedrals being built. The ad santos burial, i.e. close to the saints to be protected, became the fundamental reason for interring the dead in churches or in the space around them (cemeteries) ${ }^{3}$. The purpose of creation, according to Oriental Christianity, is rendering man and the university divine. The whole economy of redemption, Christ's salvation work, the holy action of the Holy Spirit, aim at leading the fallen humanity back to the end it was created for, towards the wholesome experience of becoming divine. According to the Holy Fathers, only by Parousia will people fulfill the purpose they were created for, and the final state of many will be decided only at the time of the Final Judgement. Until Resurrection, the saints themselves, although close to Christ, are in a state of perpetual wait.

\section{THE CONTEMPORARY OUTLOOK ON DEATH}

The manner in which the old Church imagined the situation of various categories of the dead waiting for Parousia could be summed up as follows: Christian thinking is absolutely unanimous in stating that our earthly existence is unique. Christian faith cannot reconcile this with any other concept related to successive lives and reincarnation. Such concepts can often be found with non-Christian philosophical and religious trends, especially of far Oriental origin, and are entirely alien to Christianity. It is a fundamental belief of faith that earthly life is unique and that man's fate is at stake during this unique earthly existence.

After death, the soul remains equally alive, equally aware, equally active as during its earthly existence, but in a different way. However, man/soul, after death, can no longer do anything for his/its own redemption, he/it cannot even communicate with the living, unless upon receiving divine permission, and, thus, any magical conjuring of the dead, as a psychicmystical form of communication and spiritism was condemned both by God's Word in the Old Testament, and by the Christian Conscience over the centuries: "Let me not find among you those who put their son or daughter through fire, or oracles, or fortune-tellers, or wizards, or spell-casters, or exorcists, or apparition-whisperers, or magi, or those who talk to the dead. For everything they do displeases God, and such horridness banishes God away from you" (Dt 18, 10).

${ }^{2}$ Pr. prof. dr. Ioan C. TEȘU, "Taina morții în spiritualitatea ortodoxă" ["The Sacrament of Death in Orthdox Spirituality"], in: Teologia și Viața [Theology and Life], no. 5-8, May-August, (2010), p. 5-33, here p. 6; also see Ierom. Savatie BAșTOVOI, "Invitație la moarte" ["Invitation to Dying"], in: John Breck \& com., Ce este moartea? [What Is Death?], Cluj-Napoca, Patmos, 2006, p. 49-58, here p. 51.

${ }^{3}$ cf. Jacques LE GoFF, Il cielo sceso in terra. Le radici medievali dell'Europa [The Sky Descended on Earth. The Medieval Roots of Europe], Rome-Bari, Laterza, 2007, p. 68. 
Modern and post-modern society is marked by the cultural rejection of death. Death is no longer a part of the real experience, it cannot be visible, having all its sign hidden, ante and post mortem ${ }^{4}$.

The origins of the phenomenon must be identified in the cultural transformation resulting from the process of impropriating culture and from the prevalence of anthropocentric visions, incapable of comprehending the spiritual-sacred dimension of existence beyond any value created by man, who only assesses parameters meant to evaluate the quality of life. The emergence, in particular, of some values, such as happiness, beauty, youth, physical and economical efficiency, and, at the same time, the development of biomedical techniques and technologies, which support the illusion that there are no barriers in man's control over nature, determines a change in the paradigm where death is conceptualized and experienced. Man, the absolute master of his own life, can escape the implicit limitations of the human existence. Death thus becomes an absurd, tragic event ${ }^{5}$. The contemporary man is trying to live his life to the maximum, wanting to have a taste of most of its pleasures, if not all of them, without giving too much thought to a possible future life $^{6}$. A new idea of death - reversed, censored death ${ }^{7}-$ replacing everything that people believed or experienced in the past, replacing the idea of death as passing from one life to another, serenely accepted and experienced, with a wide array of relations typical of the romantic age, which exalts and dramatizes the lover's death, rendered acceptable by the idea of continued existence in the memory of family members, fed, ceaselessly, by worshipping graves and cemeteries. Nowadays, death should not be mentioned in language, in feelings or in habits. It must be forgotten, a private, individual fact, and, if it happens, it must be assigned to funeral homes.

Atomizing death by means of logical resoning does not succeed in reducing it to a case of demythologized life, which is "implicit": it is not by murdering death in a logical manner that one achieves serene life.

The $20^{\text {th }}$ century frees itself from ("the obsession of") death, by hiding it, according to the moral duty of preserving man's happiness.

Hypocrisy, lies and secrets surround death and the dying, reduced to the captivity of the hospital. In fact, we can identify various forms of denying the event, such as giving up or shortening the period of wearing mourning clothes, the corpse's make-up, the most emblematic being the medication of the terminal stages of life. Even the dying voluntarily embraces this lie about the reality of death, protecting himself and being shielded by his own emotions when facing death, by the so-calles formula: out of love, out of pity, he does not want to be told about his actual life status ${ }^{8}$. Moreover, after the moment of death, mourning signs are also abolished at an individual and social level. This profile also includes keeping children away from any contact with the dead and protecting them from any other sign that would remind them of death ${ }^{9}$. This attitude originates in the fear that facing this moment

\footnotetext{
4 Max SCHElER, Il dolore, la morte, l'immortalità [Pain, Death, Immortality], Turin, ElleDiCI, 1983, p. 75-130, here p. 95 .

5 Metropolitan ANTONIE of SuRoJ, Despre lucrurile de pe urmă [On Final Things], Bucharest, Sofia, 2021, p. 78.

${ }^{6}$ I. C. TEȘU, Taina morții... [The Sacrament of Death...], p. 6.

${ }^{7}$ D. TetTAMANZZI, Dizionario di Bioetica [Dictionary of Bioethics], p. 294.

${ }^{8}$ Maurizio CHIODI, Etica de la Vita [The Ethics of Life], Milan, Edizioni Glossa, 2006, p. 181.

${ }^{9}$ Guido Davanzo, "Morte/ risurrezione" ["Death/ Resurrection"], in: Nuovo Dizionario di Spiritualita [The New Dictionary of Spirtuality], Milan, San Paulo, 1985, p. 144 -1055, here p. 1043.
} 
may end up in final failure, a catastrophy ${ }^{10}$ that affects man body and soul, true for everybody in a different manner. This is why, irrespective of the cost, it is necessary to run away, so as to diminish all feelings of anxiety, of tensed waiting, in a word, of all angst that arises around that moment calculated as possible failure ${ }^{11}$. No matter how sublime this running away is, it can turn into trivializing life and death. On the contrary, accepting death, even if not so serenely done, may lead to an honest communication on both parts: doctor patient, patient - doctor. We can say that a new science has emerged: mortuary science. It aims at finding the most convenient means of stripping all feelings related to death and mourning ${ }^{12}$. This way of contemplating death is certainly not new in the history of mankind, but it is new in the manner of bringing up this event. Similarly, freeing oneself from this difficult challenge - death - used to be expressed by some attempts at intellectualphilosophical trends, represented by some Antiquity and modern personalities such as Epicurus, Seneca, Epictetus, Marcus Aurelius, Descartes, Spinoza, Leibnitz, Nietzche, Camus and Malraux - with some, being a natural fact, with others, a refuse, a revolt, an exaltation, or an absurdity of the human condition ${ }^{13}$.

Contemporary society, incapable of expressing a cultural image of life aware of the moment of death - understood as the natural end of a possible existence - best hides the end of life in the hospital; formally, in order to provide better medical care for terminally ill patients, essentially, so as to escape the psychological and emotional burden. And here, in the hospital, an accord is reached with the empire of technology, with the bureaucracy of the medical practice and the concepts of organizing medicine, and, eventually, with health care workers, ill-prepared to deal with death and its general needs. Thus, death, devoid of meaning, also loses its nature as a human experience, constitutively relational and allencompassing.

Nowadays, society responds to the present experience of death by using the qualityof-life ${ }^{14}$ criterion, according to which life and death are dignified only when individuals fully assume direct and personal management. The value expressed by contemporary society is no longer that of the sacrality of life, which, at an absolute level, is sacred for the individual and for third parties, but that of the quality of life which assesses life according to criteria of quantity, efficiency, dependent on the principle of proportionality, so as to make the best decision in applying care to the ill $^{15}$. In this context, the way of living is subjected to a different and positive assessment, that of moral and legal justifiability, as a consequence of a qualitative evaluation of life, and, therefore, of rendering relative the value of life itself. For example, the proliferation of the so-called centres for palliative care, also known as medical residences, is a positive manifestation of the enhanced preoccupation with the contemporary

\footnotetext{
${ }^{10}$ M. SCHELER, Il dolore,... [Pain, ...], p. 95.; also see † ANTONIE OF SUROJ, Despre lucrurile de pe urmă [On Final Things], p. 54.

${ }^{11}$ Klaus DEMMER, "Eutanasia" ["Euthanasia"], in: Nuovo Dizionario di Teologia Morale [The New Dictionary of Moral Theology], Milan, San Paulo, 1990, p. 394-406, here p. 398.

${ }^{2}$ Amilcare GIUDICI, "Morte" ["Death"], in: Nuovo Dizionario di Teologia [The New Dictionary of Theology], Milan, San Paulo, 1988, p. 954-967, here p. 956.

${ }^{13}$ Ibidem.

14 Sandro SpINSANTI, "Vita fizica" ["Physical Life"], in: Tullo GofFI-Giannino PIANA, Corso di Morale [A Course in Morale], vol. 2, Brescia, Queriniana, 1990, p. 127-281, here p. 205.

15 Ibidem, p. 206; also see D. TETTAMANZZI, Dizionario di Bioetica [Dictionary of Bioethics], p. 295; also see Victor PAJARES, "La qualita di vita nel paziente terminale: valido criterio di giudizio?" ["The Quality of Life with Terminal Patients: Valid Judgment Criterion?'], in: Studia Bioethica [Bioethics Studies], vol. 3, no. 1-2, Rome, Italy, (2010), p. 93-96, here p. 95.
} 
sensitivity towards the quality of the patient's life during the final chapter of his existence. As we all know, palliative medicine does not claim to cure, but by undertaking such a task or mission belonging to medicine, truth be told, utilitarian, and according to others, hedonistic in respecting the quality of life, it cares for the person facing death at any moment, when there is no chance for a patient to be cured ${ }^{16}$.

Modern society is terrified of death. And for a good reason.

Once human life has been denied any transcendental meaning, reduced to the biological life of a machine-body ${ }^{17}$, death can only be defined as the trivial interruption in the functionality of a machine and the non-recurring end, meaningless for each man. Hence, this end must be hidden, with all the its reminders, starting with the cemetery. In this grasp of "metaphysical relaxation" 18 , the phenomenon of death, reduced to the biological fact, is timed, quantified, measured with precision. Death thus acquires a technological dimension, where the sole competence pertains to the doctor ${ }^{19}$, whereas the dying becomes an isolated "something" 20 . Consequently, the close connection between life and death is lost and individualism enhances the isolation of the person suffering; death is ultimately understood as desocializing ${ }^{21}$.

In fact, culturalizing the phobia of real deaths is ostentatiously accompanied by a sort of panic of fictitious deaths: celebrating, on TV and in cinemas, the cruel rite of deaths, both numerous and fake and horrible, represents an obsessive effort of stripping real deaths, without special effects, but endowed with that natural effect of radically asking the question about significance, at the same time excluding any partial, fictious or evasive answer. The spectator is not called upon to answer the questions that the dying individual is asking himself - and the magna quaestio that he himself has become ${ }^{22}$ - but, on the contrary, he feels freed facing fictious deaths.

One of the most important methods used for cover-up nowadays, deceiving the experience of facing death is surely hospitalizing and medicalizing it: the so-called "terminal" patient - one of the numerous linguistic strategies employed to hide the reality of death and that of "passing away, dying" - is isolated from the rest of the community, frequently abandoned by family and friends, and entrusted solely to the care of the medical personnel. Doctors and - above all - nurses, silently invested with authority by a society that flees from death and from any of its meanings, end up having to manage the majority of deaths, bearing the heavy burden of answering the questions of those they care for: why am I

\footnotetext{
${ }^{16}$ V. PAJARES, "La qualita di vita..." ["The Quality of Life...”], p. 93.

${ }^{17}$ Cf. Lorenzo CANTONI, "La Carta degli Operatori sanitari. Una presentazione" ["The Charter of Health Care Workers. A Presentation”], in: Cristianità [Christianity], year XXIII, no. 239, May (1995), pp. 6-10.

${ }^{18}$ Martin HeIDEGGER, Esere e tempo [Being and Time], translated by Pietro Chiodi, Milan, Longanesi, 1976, p. 308.

${ }^{19}$ M. CHIODI, Etica de la Vita [The Ethics of Life], p. 182.

${ }^{20}$ Renato ZANCHETTA, "L'evento della morte nella realtà e nella cultura odierna. Aspetii antrolpologici e sociologici" ["The Event of Death in Contemporary Reality and Culture. Anthropological and Sociological Aspects"] in: Rivista Liturgica [Liturgical Magazine], no. 5, September-October, Messagero, Padua, (2006), p. 673-684, here p. 677.

${ }^{21}$ Ibidem, p. 679.

${ }^{22}$ Cf. Stanislaw GRYGIEL, "La salvezza e la salute" ["Salvation and Health"], in: Ermanno Pavesi (ed), Salute e salvezza. Prospettive interdiscliplinari [Health and Salvation. Interdisciplinary Perspectives], Milan, Di Giovanni - San Giuliano Milanese 1994, p. 17-36 here p. 27: "When facing death, man begins to wonder about the significance of his being who is born and dies, that is the truth about himself. When facing death, any meaning of death conceived and created by man bears no importance. In other words, before dying, the 'magna quaestio' arises".
} 
alone now, why now, what will happen to me, but also that of fulfilling the need and request for affection, compassion, and warmth. What is more, modern medicine so much multiplies its specialized fields and technologizes its manner of curing, that it tends to forget the human-spiritual dimension of caring for people's health ${ }^{23}$.

The members of the medical personnel, whose wide-spread culture allows them to perceive themselves only as "health care technicians" for the machine-bodies, have to face and run away from the complete and final failure of their activity. Health care workers are called upon to be in the service of death, and this comes as an obligation meant to respond to other people's rights. Doctors, nurses, pharmacists should consider, as their duty and responsibility, a prompt collaboaration in favour of a "culture of death". Their work, implicitly meant to protect physical life, should preferably peacefully coexist with their work of procuring death. Without a shadow of a doubt, a doctor's duty of warranting life cannot be questioned, but there are plenty of questions regarding the exact determination of the limitations of his actions, especially in borderline situations ${ }^{24}$.

This antinomy is obvious when one states that: the medical and health care activity relies on an interpersonal relationship of a certain nature; that it represents the convergence of trust and conscience. "The 'trust' of a man marked by suffering and illness, and he must, therefore, entrust himself to the 'conscience' of another man who can take over the burden of his need and who meets him half way in order to help him, cure him." "25. Here, at least beginning with Hippocrates' oath, the only genuine profile of health care workers is that of being the organs of a culture of life. Unfortunately, their duties and responsibilities have been moving in the opposite direction for quite some time. Certainly, the perspective of death, no matter how difficult notifying people about it may be, does not absolve us from telling the truth. The medical and health care activity reveals itself here, relying on the convergence of trust and conscience, in its crucial moment. The trust of a man marked by death becomes an appeal to the conscience of the health care worker rather than to science. The individual's right to be informed about his life state inevitably places health care workers on the path of their specific duty and responsibility. This obviously requires insight and great finesse. It is all about establishing a solidarity relationship with the terminally ill patient, where it is not that necessary to communicate clinical data to him, but to focus on revealing meanings that would lead to good communication and honesty. The patient must not feel alone in his illness, but understood in the true state of his condition and a part of his fellow-men's love. Without a Christian dimension to it, medicine fails its purpose and its place within culture is at great risk of being severely distorted ${ }^{26}$. Without orienting itself towards God's Kingdom, it is in danger of becoming a practice ill-shaped by politics and economic power, a reality in itself and for itself $^{27}$, insisting on the biological part of man, without taking into consideration an individual's dichotomic and mystical constitution. It is true that medicine as an institution, and not as charity or therapy, has taken time to reach its

\footnotetext{
${ }^{23}$ S. SPINSANTI, "Vita fizica" ["Physical Life"], p. 204.

${ }^{24}$ K. DEMMER, "Eutanasia" ["Euthanasia"], p. 394.

25 Pontificio Consiglio della pastorale per gli operatori sanitari 1995 [Pontifical Council of the pastoral for health care workers], Carta degli Operatori sanitari [The Charter of Health Care Workers], no. 2.

${ }^{26}$ H.Tristram ENGELHARDT JR., Fundamentele Bioeticii creștine [The Fundamentals of Christian Bioethics], Sibiu, Edit. Deisis, 2005, p. 411.

${ }^{27}$ Jean-Claude LARCHET, Teologia bolii [The Theology of Illness], Sibiu, Edit. Oastea Domnului, 1997, p. 9.
} 
current level, from Hippocrates and that miserium fascinosum et tremendum, to Cartesius (Descartes) with "maitres et possesseurs de la nature" 28.

If the contemporary situation of medicalizing and hospitalizing death constitutes one of the most important historical conditions meant to help us frame the current debate on death, then mention must be made here: death no longer has any sacrament, in other words, its transcendental meaning has been tampered with. It is a sort of "checkmating" death, achieved by a permanently institutionalized medicine, and, why should we refrain from saying it, constantly politicized, even from this perspective of scientific noblesse ${ }^{29}$.

Nowadays, people talk about "humanizing medicine" - which consists in acknowledging the individual's dignity, that of each human being, starting from the moment of conception, up to the moment of death, being aware of his spirituality and immortality. Each individual, by his own unique way of being, is not only made up of the body, but also of the soul, so that the body is given, according to Christian Teaching, at the moment when the souls comes in as well, forming what is called, from a Christian perspective, the human being. Respecting somebody's dignity entails saving and defending this body-and-soul dichotomic identity ${ }^{30}$. No doctor can logically claim, as a result of his scientific competence, that he can decide man's origin or fate. This rule can also be particularly applied to problems raised by sexuality, or procreation, where man and woman apply the fundamental values of love and life. Physical life definitely does not exhaust an individual's value, nor does it represent the ultimate good for man, which means that man has a fundamental part that moves the biological and which remains hidden to medical science, but which can be disrupted from performing well by therapeutic persistence ${ }^{31}$.

\section{CONCLUSION}

Confronted with the trauma of death, human behaviour reacted socially with mourning rituals, which do not attempt to remove death, but rather to achieve a realistic acceptance of it and to promote getting over the shock, looking both for the meaning both of death and of the life which goes on. Thus, there is community conscience of being part of the living and of the dead; the relationship with those who are no longer with us continues after death and there is a feeling of their presence and actions. Therefore, the dead are still alive. The Proskomedia and the Holy Liturgy, the Saturdays of Souls in Orthodox spirituality, as well as the Sunday of All Saints both with the Orthodox, and with the Catholics, transform fear of death into a celebration of the sacrament of death and of the hope for eternal life: "And if they preach that Christ became resurrect, how can some of you say that there is no such thing as resurrection? And if there is no resurrection of the dead, then Christ did not become resurrect either. And if Christ did not become resurrect, in vain is then our preaching, in vain is your faith, as well" (I Cor. 15, 12-14). Orthodox experience, founded on revelation and the testimonies of the Western or Eastern Holy Fathers, assures man that death is not a fiasco, a failure, but a wide gate, through which man enters another life and another world, happy or sad, according to his deeds in his earthly world and life ${ }^{32}$.

\footnotetext{
${ }^{28}$ Sandro SPINSANTI, "Salute, malattia, morte" ["Health, Illness, Death"], in: Nuovo Dizionario di Teologia Morale [The New Dictionary of Moral Theology], Milan, San Paulo, 1990, p. 1134-1144, here p. 1141.

${ }^{29}$ Ibidem.

${ }^{30}$ Pr. Leontin PoPESCU, Bioetica și perspectiva creștină [Bioethics and The Christian Perspective], Brăila, Istros, 2009, p. 48.

${ }^{31}$ D. TetTAMAnZZI, Dizionario di Bioetica [Dictionary of Bioethics], p. 291.

${ }^{32}$ I. C. TEŞU, "Taina morții..." [“The Sacrament of Death...”], p. 7.
} 
"Nor can we excuse that kind of impatience (when losing our loved ones), - says church writer Tertullian - where a certain share of grief can be accepted. We must first consider the Apostle's words, which say: 'Do not be sad about somebody's passing away, like pagans are, for they lack hope.' And rightfully so. For those of us who believe in Christ's resurrection also believe in our own resurrection, of those for whom $\mathrm{He}$ died and became resurrect. So, where there is resurrection of the dead, there is no pain in death, no impatience in grief. Why should you feel grief if you do not believe that you perished? Why should you be impatient that the one who will come back has gone away for a while? What you perceive as death is just departure" 33 .

The Christian proposition regarding the victory over the reign of death comes out of the Easter experience, when the God of life, and loving life, unites mankind to the point of vanquishing the reign of their mutual enemy, but exceeding it by Christ's resurrection, who becomes an archetype for the entire humanity (1 Cor 15). This is magisterially said by Saint John Chrysostom in his homily against those who get drunk on Easter night: "The Lord has become resurrect, and with Him, the whole world has become resurrect; He has become resurrect, shattering the bonds of death. Adam made a mistake and died, but Christ made no mistake and still died. This is a wonderful thing beyond the natural: that one was wrong and died, but this One was not wrong and also died. What for? So that the one who was wrong and died could be freed from the bonds of death by the One who was not wrong and died"34.

The faith in resurrection bestows meaning upon this great Sacrament of life: namely that death is not destruction, disappearance, but meeting again.

\section{BIBLIOGRAPHY:}

[1] AnTONIE, Metropolitan of Suroj, Despre lucrurile de pe urmă [On Final Things], Bucharest, Sofia, 2021.

[2] ARIES, Philipe, Storia della morte in Occidente dal Medioevo ai nostri giorni [The History of Death in the West from the Middle Ages to the Present], Milan, 1978.

[3] BașTovoI, Ierom. Savatie, "Invitație la moarte" ["Invitation to Dying"], in: John Breck \& com., Ce este moartea? [What Is Death?], Cluj-Napoca, Patmos, 2006, p. 49-58.

[4] Cantoni, Lorenzo, "La Carta degli Operatori sanitari. Una presentazione" ["The Charter of Health Care Workers. A Presentation"], in: Cristianità [Christianity], year XXIII, no. 239, March (1995), p. 610.

[5] Chiod, Maurizio, Etica de la Vita [The Ethics of Life], Milan, Edizioni Glossa, 2006.

[6] Davanzo, Guido, "Morte/ risurrezione" ["Death/ Resurrection"], in: Nuovo Dizionario di Spiritualita [The New Dictionary of Spirituality], Milan, San Paulo, 1985, p. 144 -1055.

[7] Demmer, Klaus, "Eutanasia" ["Euthanasia"], in: Nuovo Dizionario di Teologia Morale [The New Dictionary of Moral Theology], Milan, San Paulo, 1990, p. 394-406.

\footnotetext{
${ }^{33}$ Quintus Septimius Florens Tertullianus, "De Patientia”, in: JP. Migne, Patrologia Latina. vol. 1, col. 1359-1386, here col. 1374C-1375A: "Ne illa quidem impatientiae species excusatur in amissione nostrorum, ubi aliqua doloris patrocinatur affectio. Proponendus denuntiationis Apostoli qui sit (Thess.IV): ne contristermini dormitione cuiusquam sicut nationes quae spe carent. Et merito. Credentes enim resurrectionem Christi, in nostram quoque credimus, propter quos ille et obiit et resurrexit. Ergo cum constet de resurrectione mortuorum, vacat dolor mortis, vacat et impatientia doloris. Cum ergo doleas si periisse non credis?Cur impatienter feras subductum interim, quem credis reversurum? Profectio est, quam putas mortem."

${ }^{34}$ S. JoAnnes Chrysostomus, "Adversus Ebriososo et De Resurrectione, sermo habitus in sancta et Magna Dominica Paschae", in: JP. Migne, Patrologia Graeca, vol. 50, col. 433-442, here col. 438: "Resurrexit enim Dominus secumque suscitavit orbem terratum, ipse siquidem disruptis mortis vinculis resurrexit. Peccavit Adamus et mortuus est: at non peccavit Christus, et mortuus est. Novum est hoc et admirabile; elle peccavit, et mortuus est; hic non peccavit, et mortuus est; quid ita? Quo is qui peccavit et mortuus est, eius opera qui non peccavit quidem, mortuus est autem, mortis nexus possit evadere".
} 
[8] EngelhardT JR, H. Tristram., Fundamentele Bioeticii creștine [The Fundamentals of Christian Bioethics], Sibiu, Edit. Deisis, 2005.

[9] GIUDICI, Amilcare, "Morte" ["Death"], in: Nuovo Dizionario di Teologia [The New Dictionary of Theology], Milan, San Paulo, 1988, p. 954-967.

[10] GrYGIEL, Stanislaw, "La salvezza e la salute" ["Salvation and Health"], in: Ermanno Pavesi (ed), Salute e salvezza. Prospettive interdiscliplinari [Health and Salvation. Interdisciplinary Perspectives], Milan, Di Giovanni - San Giuliano Milanese 1994, p. 17-36.

[11] HeidegGer, Martin, Esere e tempo [Being and Time], translated by Pietro Chiodi, Milan, Longanesi, 1976, p. 308.

[12] LARCHET, Jean-Claude, Teologia bolii [The Theology of Illness], Sibiu, Edit. Oastea Domnului, 1997.

[13] LE GOFF, Jacques, Il cielo sceso in terra. Le radici medievali dell'Europa [The Sky Descended on Earth. The Medieval Roots of Europe], Rome-Bari, Laterza, 2007.

[14] Pajares, Victor, "La qualita di vita nel paziente terminale: valido criterio di giudizio?" ["The Quality of Life with Terminal Patients: Valid Judgment Criterion?"], in: Studia Bioethica [Bioethics Studies], vol. 3, no. 1-2, Rome, Italy, (2010), p. 93-96.

[15] PoPeSCu, pr. Leontin, Bioetica și perspectiva creștină [Bioethics and the Christian Perspective], Brăila, Istros, 2009.

[16] S. JoAnnes Chrysostomus, "Adversus Ebriososo et De Resurrectione, sermo habitus in sancta et Magna Dominica Paschae”, in: JP. Migne, Patrologia Graeca, vol. 50, col. 433-442.

[17] SCHELER, Max, Il dolore, la morte, l'immortalità [Pain, Death, Immortality], Turin, ElleDiCI, 1983.

[18] SPINSANTI, Sandro, "Salute, malattia, morte", in: Nuovo Dizionario di Teologia Morale [The New Dictionary of Moral Theology], Milan, San Paulo, 1990, p. 1134-1144.

[19] SPINSANTI, Sandro, "Vita fizica" ["Physical Life"], in: Tullo GofFI-Giannino PIANA, Corso di Morale [A Course in Morale], vol. 2, Brescia, Queriniana, 1990.

[20] Tertullianus, Quintus Septimius Florens, "De Patientia", in: JP. Migne, Patrologia Latina. vol. 1, col. 1359-1386.

[21] TEșu, pr. prof. dr. Ioan C., "Taina morții în spiritualitatea ortodoxă" ["The Sacrament of Death in Orthodox Spirituality"], in: Teologia și Viața [Theology and Life], no. 5-8, May-August, (2010), p. 533

[22] TettamanzzI, Dionigi, Dizionario di Bioetica [Dictionary of Bioethics], Casale Montferrato, PIEMME, 2002.

[23] ZANCHETTA, Renato, "L'evento della morte nella realtà e nella cultura odierna. Aspetii antrolpologici e sociologici" ["The Event of Death in Contemporary Reality and Culture. Anthropological and Sociological Aspects"] in: Rivista Liturgica [Liturgical Magazine], no. 5, September-October, Messagero, Padua, (2006), p. 673-684. 